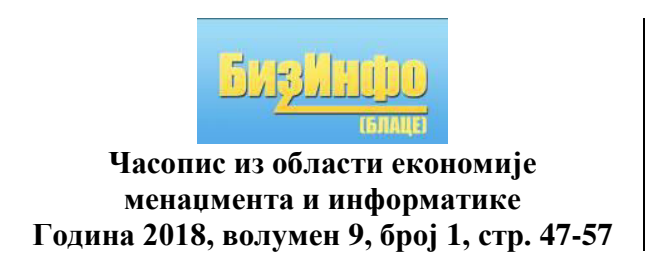

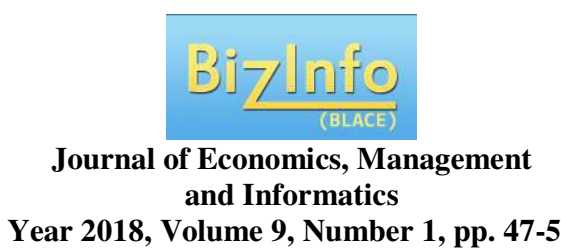

Year 2018, Volume 9, Number 1, pp. 47-57

Стручни рад/ Professional paper

УДК/UDC: 005.21

658.4:005.51(497.6 PC)

\title{
DEVELOPMENT OF THE STRATEGIC PLANNING PROCESS NECESSARY FOR THE BUSINESS PERFORMANCE QUALITY IMPROVEMENT IN SMALL AND MEDIUM COMPANIES
}

\section{РАЗВОЈ ПРОЦЕСА СТРАТЕШКОГ ПЛАНИРАЫА ПОТРЕБНОГ ЗА ПОБОЉШАЫЕ КВАЛИТЕТА ПОСЛОВНИХ ПЕРФОРМАНСИ У МСП}

\author{
Boris Valjevac \\ Bemind, Banja Luka, Republic of Srpska, Bosnia and Herzegovina \\ Ljiljana Sorak \\ Komercijalna Banka ad. Banja Luka, Republic of Srpska Bosnia and \\ Herzegovina \\ Miloš Sorak ${ }^{1}$ \\ Faculty of Technology, Banja Luka, University of Banja Luka, Republic of \\ Srpska, Bosnia and Herzegovina
}

Abstract: This study shows model of strategic planning process development, which consists of the vision, mission and strategic goals, for the purpose of business performance quality improvement in small and medium enterprises. Conditions for establishing measurable business goals are formed by defining strategic plan, which is the precondition for monitoring the quality of company's business performance. The first phase of this study referred to explaining the term and defining strategic management process. The second phase shows the process of making strategic plan for a selected company. Key words: strategic plan, process, management, business performance, small and medium enterprises

${ }^{1}$ sorakmilos@yahoo.com 
Сажетак: Ова студија показује модел развоја стратешког планирања, који се састоји од визије, мисије и стратешких ициьева, у иильу побољшања квалитета пословања у малим и средњим предузећима. Услови за успостављање мерливих пословних циљева се формирају дефинисањем стратешког плана, што је предуслов за праћење квалитета пословаға компаније. Прва фаза ове студије односила се на објашњавање појма и дефинисање процеса стратешког менаимента. Друга фаза показује прочес израде стратешког плана за одабрану компанију.

Кључне речи: стратешки план, прочес, управљање, пословне перформансе, мала и средња предузећа

\section{INTRODUCTION}

Under today's conditions only those small and medium enterprises which have the ability to continuously and quickly adjust to ever changing conditions manage to stay at the market. To put it other words, only the best stay at the market, because a buyer expect top quality which fulfills all his needs and wants, and at the same time, he is prepared to pay only the price which is cheaper than competitor's. So, a buyer expects value for himself, which is a lower price and a higher quality.

In order for small and medium enterprises to meet the stated demands, they have to develop strategic management process. This is a process which consists of certain procedures and measures which need to be done at the company's level in order to achieve long term sustainability, development or growth. The process consists of: environmental analysis, organizational guidance, strategy formulation and implementation.

Developed strategic management process should give a frame for transformation of company's vision, mission and strategic goals into measurable business goals, so that company's performance in key business areas can be measured. In this way it is possible to manage with better quality business performance of small and medium enterprises in the future. This should also be the basis for business quality improvement of small and medium enterprises.

\section{STRATEGIC MANAGEMENT PROCESS}

Strategic Management is a process of permanent adjustment of a company to changing environment. It determines different paths which will provide survival, development and growth to a company. Considering that Strategic Management is turned toward organizational environment, it should provide its effectiveness, i.e. that the right things are done. Doing the right thing 
DEVELOPMENT OF THE STRATEGIC PLANNING PROCESS NECESSARY FOR THE BUSINESS PERFORMANCE QUALITY IMPROVEMENT IN SMALLAND MEDIUM COMPANIES

means supplying buyers on time with products and services of high quality, certain type and quantity.

There are several definitions of Strategic Management:

- Kotler (1988) defines Strategic Management as a management process of developing and maintaining the viability, objectives and resources of the organization in relation to the possibilities of its environment.

- Anđelić (2008) defines Strategic Management as a science or art of formulating, implementing and grading decisions which will provide to organization to achieve its goals.

- Wells (2000) Strategic Management is a process used by leader of a company to predict its future and develop necessary procedures and operations to achieve that future.

- Todorović (2003) defines Strategic Management as a process of guiding organization's activities which, based on opportunities and threats on one side and strengths and weaknesses on the other, identify critical factors of business success.

Today Strategic Management process is differently defined in different schools of management. The sequence of phases (steps) is defined differently, and even certain phases are differently interpreted. But regardless of different interpretations, strategic management defines comprehensive concept of achieving company's goal in certain environment.

According to Mašić (2007), strategic management process consists of the following five steps:

- Environmental analysis,

- Organizational guidance,

- Strategy formulation,

- Strategy implementation,

- Strategic control.

Environmental analysis is performed because of more clear definition of present and future state of the organization and environment. Because of that detailed research of the environment is performed, with the goal to predict the changes which will take place and which will have an impact on company's functioning. After environmental prediction, the state of the company is analyzed, which should show its ability to sustain, develop or grow.

Prediction process analysis in the company has included:

- Analysis of the influential environmental factors which cause changes and influence company, and 
- Analysis of the potential which company has.

For the stated analysis SWOT analysis was used. The term SWOT is acronym from the following English words:

- S - Strengths,

- W - Weaknesses,

- O - Opportunities,

- T - Threats.

SWOT analysis is conducted through three phases.

In the first phase of SWOT analysis identification of key macro, micro and internal environment parameters is performed.

The second phase refers to sorting parameters into groups: threats, opportunities, strengths and weaknesses and its display in SWOT matrix. Sorting parameters per groups: threats, opportunities, strengths and weaknesses is showed in SWOT matrix.

Third phase refers to detailed analysis of SWOT matrix (Carić et al, 2005).

In order to fulfill its function, company first has to develop appropriate process of developing strategic plan. Strategic planning in fact provides for present decisions to be made as seen in the light of their realization, i.e. future. This doesn't mean making future decisions. Decisions are made now and their realization will happen in the future. The purpose of strategic planning is recognizing expected future events and activities which will happen with the changes in the system and in the environment (Šehić, 2001).

Business is a dynamic process, and goals and strategies must be continuously reviewed, so that the company can readily respond to competition and technology development (Mihailović, et al., 2011).

Given that the modern business environment is characterized by a high degree of uncertainty, the company's endurance and success primarily determines the ability of management to create a strategy that, under given conditions, contributes to achieving goals. Information obtained by scanning the external environment and analyzing internal environments is the basis for strategic planning and decision-making (Brnjas and Tripunoski, 2016).

Business-based activity-based planning is a dynamic process that highlights customers' demands in the first place and determines appropriate activities and resources, both financial and operational, necessary for carrying out these activities and timely response to demands from the sales market. It provides a detailed analysis of the necessary resources and their comparison with 
DEVELOPMENT OF THE STRATEGIC PLANNING PROCESS NECESSARY FOR THE BUSINESS PERFORMANCE QUALITY IMPROVEMENT IN SMALLAND MEDIUM COMPANIES

existing ones for the purpose of more effective and efficient use and management (Gooderham, G., 2001, 29- 43)

Environment is which a company is performing its function contains numerous threats and dangers. Under such conditions it is necessary to apply strategic planning, which helps managers greatly, since it makes possible the preparation for versatile environment. In this way the organization becomes flexible and better prepared to respond to environmental challenges.

Creating strategic goals of the company during the strategic planning process reveals the implications for the goals of managers and harmonises individuals with the strategic goals of the company as a whole (Anđelkovic et al, 2012). If owners of SMEs adequately perceive the capabilities of their company, make the right decisions, find effective solutions in terms of organization and apply modern control approaches and the success of the company will definitely follow (Lazarević-Moravčević et al., 2017). Managers who are willing to change their business paradigms and are open to applying managerial tools to improve performance can achieve business results (Dobrosavljević and Urošević, 2017). Managers have determined that it is possible to better channel organizational direction with precisely defined strategic plan. Strategic plan is most commonly presented via vision, mission and strategic goals.

Vision is seeing what a company could become in future. Vision should provide for all members of an organization and other interested parties (buyers, owners, suppliers and society) to be persuaded in rightfulness of the projected future. Vision of an organization is most commonly given via short succinct slogan, which serves as a business password, and a short description in a few sentences which practically explains how the vision will be achieved in the future.

Mission gives identity to an organization. It, in fact, provides answer the question: what is company's business, i.e. what is the basic purpose of company's existence. Mission defines and further determines organization's vision from the aspect of basic choices and organizations intentions. It replies to question HOW to achieve imagined picture of the future. Company's possibilities, opportunities and threats from the environment are taken into consideration, just like demands from the interested parties (owners, employees, buyers, suppliers and society).

Strategic goals present primary planned decisions, considering that vision and mission its first realization achieve through formulating goals. They practically reply to question WHAT, WHEN and HOW MUCH. Strategic 
goals directly or indirectly influence all business aspects in organization because all of its activities are corrected and guided toward set goals.

The strategy selects the way for the realization of the company's mission and goals in a given environment. Its purpose is to provide adequate relation between environment and company's resource possibilities, as well as to reduce or eliminate the gap between potential and present performances in company's business. Practically, strategy is between mission and goals on one, and tactical planning on the other side, because strategy transforms mission and goals into directions and methods of company's acting. As planned decision, it specifies company's behavior toward targeted market.

Strategy formulation is a process in which comprehensive approach toward transformation of the present state into some future state (state defined by strategic plan) is developed. This process is very complex due to existence of numerous aspects and variables which have to be taken into consideration. Process of determining strategy consists of defining measures which have to be conducted in order to achieve stated strategic goals.

So, a strategy is a hypothesis of what is believed that will function and be successful after its implementation. That is why the steps in creating BSC method should provide test base to determine if the strategy is going to work, how efficiently it will work and how effective will be organization in moving toward achieving its goals. That is why modern organizations, beside general strategy develop also a business strategy, and in certain cases even functional strategies.

In order for a company to achieve its mission and goals it is not sufficient to just choose a strategy, but also to implement it. Strategy implementation transforms conceptual solution to practical achievements. This implies that:

- Goals are turned into tasks;

- Activities are identified;

- Resources are allocated;

- Organizational structure is created and

- Business culture is established.

When defining the strategy extrovert orientation and external horizon become emphasized, while introverted management is typical for the implementation. In the process of defining the strategy it is important to keep in mind the magnitude and type of change which its implementation is going to require.

Reasons for establishing strategic control should be searched in the fact that for efficiency and effectiveness of a company it is not enough to invest a lot of knowledge and skills into defining strategic plan and other plans which 
DEVELOPMENT OF THE STRATEGIC PLANNING PROCESS NECESSARY FOR THE BUSINESS PERFORMANCE QUALITY IMPROVEMENT IN SMALLAND MEDIUM COMPANIES

derive from it. Research shows that a lot of knowledge and skill should be invested into defining and establishing proposition for implementation of those plans into company's operating processes.

In order to avoid investing huge effort which will not result with company achieving expected efficiency and effectiveness, the process of strategic control is established. Its goal is to:

- Follow up compliance between real and planned state,

- Discover deviations between real and planned state,

- Discover contradictions between the plans and

- If necessary undertake corrective and preventive measures (Sorak, 2005).

By corrective measures it is meant measures taken to remove observed inconsistencies which appear during realization of strategic and all the other plans which derived from it. By preventive measures it is meant measures undertaken in order to remove potential inconsistencies. These are inconsistencies which couldn't be predicted during planning.

\section{THE PROCESS OF DEVELOPING STRATEGIC PLAN FOR A SPECIFIC COMPANY}

Company „BEMIND“ BANJA LUKA, was established in 1970 as a result of joint forces of several smaller handicraft firms which offered production or service. From the foundation until present, the company has worked in different organizational types, in line with the legislation. Bemind follows European and world trends in developing products from the same portfolio, it uses modern technology, it adjusts organizational structure according to the market needs, educates necessary workforce and at the moment employs around 70 people.

Bemind's main activity is in three economy areas, which are:

- Electrical sector (distribution switchboards for managing, measuring and regulating products and processes),

- Mechanical sector (metal boxes for distribution switchboards, grid columns for base stations of mobile phone operators, various metal constructions, assemblies and positions) and

- Construction sector (construction joinery made of aluminum and PVC, structural and semi-structural facades for business and residential objects).

In modern management the base and the first step from where all other activities start is the creation of organization's strategic plan. Since the entire viable future is based on it, the plan is created under constant supervision and 
instructions of top management, because they are responsible for correct definition and implementation of organizational strategy.

The essence of strategic planning is recognition of expected future events and activities which will take place when change happens in the system and environment. Under such conditions it is necessary to apply strategic planning, which greatly helps managers by allowing them to prepare for changeable environment, hence organization becomes more flexible and better prepared to respond to environmental challenges.

Precisely, based on analysis and estimate of all business performance aspects of the company in a given environment, Bemind management has defined strategic plan which is presented through the vision, mission and strategic goals (Valjevac, 2013).

Bemind's vision is stable and flexible regional company which will successfully deal with very dynamic changes in development and production of distribution switchboard systems, metal products and construction joinery.

Bemind mission is stability in fulfilling buyers expectations in terms of quality, delivery deadline and product and service price. It is presented by the following elements:

Company Bemind produces broad portfolio of products which are grouped into 3 basic economy-market groups:

- distribution switchboard systems;

- metal products;

- construction joinery.

Company Bemind is market oriented toward the following areas: Bosnia and Herzegovina, Serbia, Croatia, Slovenia, Austria and EU.

This can be observed through the following attitudes:

- We will provide products of a good quality for buyers, which will completely satisfy their expectations.

- To employees we will provide existential certainty and continuous training and improvement, so that they can better adjust to modern methods of work and business.

- We will stay loyal to our shareholders; we will insure and increase value of their investment into company's shares.

- We will invest financial resources into key supplier development process.

- We will fill our obligations toward society or regular basis, and

- We will take care of environmental protection. 
All employees of company Bemind are familiar with the adopted standards of behavior and they are required to abide by them:

- Cooperation in procedures which lead toward fulfilling company's strategy;

- Putting personal behavior and energy in the service of the company's strategy;

- Adjusting to working conditions in the environment;

- Openness for cooperation horizontally and vertically in the organization and outside;

- All employees are engaged in development and creation of company's positive image;

- Expert and experiential management mentoring in constant training of subordinates;

- acceptance and support of teamwork;

- development of creative climate in the company and

- Achieving active role of management in in achieving the standards of conduct.

Bemind's driving leverage is in rational acting and moral principles.

Based on information received from SWOT analysis which was conducted by the company management, and based on definition of the vision and mission from the first phase of strategic directing of Bemind company, strategic goals of the company were defined. Strategic goals were created as a product of vision and mission operationalization, by aggregating conclusions and attitudes toward open questions of chosen perspectives, and those conclusions and attitudes are:

- Maintaining company's achieved position with the tendency for growth;

- Constant build up and adjustment to adequate organizational structure;

- Increased productivity;

- Maintaining and strengthening of staff's potential;

- Construction of appropriate reward and stimulation system for employees;

- Application of modern technologies in the projection and production processes.

\section{CONCLUSION}

From above said it can be concluded that it is very important for an organization to develop guiding process by defining strategic plan which is most commonly presented through VISION, MISSION AND STRATEGIC 
GOALS. In this way company's ability to respond to changeable environmental conditions improves, and at the same time achieve projected efficiency and effectiveness of the organization. The following conclusions can be drawn:

1. Strategic plan is the main base and the first step in their management, from which all other activities start.

2. Correct definition and implementation of the strategic plan is responsibility of the top management, and that is why everything is done under their constant supervision and instructions.

3. Development of a strategic plan is a process that consists of certain procedures, which are commonly expressed through: vision, mission and strategic goals and

4. Defining strategic plan helps company fight against disturbance which come from the environment and from the inside.

Once developed, process of creating strategic management helps improve business performance quality in small and medium companies

\section{REFERENCES}

1. Anđelić, G. 2008. Strategijski menadžment. Novi Sad: Fakultet tehničkih nauka.

2. Anđelković Pešić M, Janković Milić, V., Stanković, J. 2012. Significance of Business Quality Management for Increasing Competitiveness of Serbian Economy. Serbian Journal of Management, Vol. 7, No 1, pp. 149-170.

3. Brnjas, Z., Tripunoski, I. 2016. Situational analysis in the function of developing company competitive advantage. Bulletin of economic research, pp. 134-153.

4. Carić N. i drugi 2005. Kreiranje poslovnih strategija, Pojmovi, principi i tehnike, Novi Sad: Adižes Southeast Europe.

5. Dobrosavljević, A., Urošević, S. 2017. Benčmarking kao menadžerski alat za dostizanje poslovne izvrsnosti malih i srednjih preduzeća u okviru tekstilne industrije. Tekstilna industrija, vol. 65, no. 4, pp. 4-10.

6. Gooderham, G., 2001. The Top 10 Lessons of Implementing Performance management systems. Journal of Cost Management, january/february, 29-43.

7. Kotler F. 1988. Upravljanje marketingom. Zagreb: Informator

8. Lazarević-Moravčević, M., Stevanović, S., Belopavlović, G. 2017. Specifics of Management in Small and Medium-Size Enterprises in Serbia. Economic analysis, 47(3-4), 104-117.

9. Mašić, B. 2007. Strategijski menadžment, proces i pricipi. Bijeljina: Univerzitet Sinergija. 
DEVELOPMENT OF THE STRATEGIC PLANNING PROCESS NECESSARY FOR THE BUSINESS PERFORMANCE QUALITY IMPROVEMENT IN SMALLAND MEDIUM COMPANIES

10. Mihailović, B., Cvijanović, D., Hamović, V. 2011. Menadžment koncepti i tehnike kao podrška poslovnom odlučivanju preduzeća. Škola biznisa, broj, 1,75-88.

11. Šehić Dž., 2001. Strategijski menadžment, Mostar: Slovo.

12. Sorak, M. 2005. Menadžment poslovnim funkcijama prema ISO 9000:2000, Banja Luka: Tehnološki fakultet.

13. Todorović, J. 2003. Strategijski i operativni menadžment, Beograd: CONZIT.

14. Valjevac B. 2013. Uticaj BSC (Balanced Scorecard) metodologije na efikasnost poslovanja malih $i$ srednjih preduzeća, Magistrski rad, UPIM, Banja Luka.

15. Vlada Republike Srpske. 2017. Strategija razvoja malih i srednjih preduzeća u Republici Srpskoj za period 2006-2010, Banja Luka: Vlada Republike Srpske.

16. Wells, L. D. 2000. Strategic Management for Senior Leaders. Arlington-Virginia: Department of the Navy Total Quality Leadership Office

17. Poslovnik kvaliteta a.d. BEMIND Banja Luka

Received: 28 May, 2018

Accepted: 2 June, 2018 
